\title{
IMPUTED CONTRIBUTORY NEGLIGENCE IN AUTOMOBILE BAILMENTS
}

\section{Russell R. Reno $†$}

The advent of the automobile has radically changed the social desirability of many established principles of law. Probably foremost among these is the question of the vicarious responsibility of the bailor of an automobile for the negligence or contributory negligence of the bailee while driving such automobile. It is the purpose of this article to discuss the question of the imputation of contributory negligence of the bailee to the bailor, in a suit by the bailor against a third party for damage to the bailed automobile. It should be noted that no attempt will be made to cover the question of imputing the contributory negligence of the bailee-driver to the bailor-passenger, where such bailor-passenger is suing the third party for personal injuries. The scope of this article will be limited to the question of the bailor's recovery for property damage only.

Prior to Igoo the adjudicated cases held that the contributory negligence of the bailee should be imputed to the bailor in a suit against a third party for damage to the bailed article. ${ }^{1}$ The basis for the holding of these cases was the theory of the identity of interests of the bailee and bailor as against third persons. ${ }^{2}$ However, with the development of the theory of distinct and separate interests of bailee and bailor in the bailed chattel, the basis for these cases broke down. These distinct and separate interests were soon recognized as existent against third parties as well as between the parties themselves. The bailee as well as the bailor was given the right to recover full damages as against the third person. ${ }^{3}$ Such damages, over and above the injury to the bailee's limited interest in the chattel, are held in trust for the bailor.* But a judgment against the bailee in a suit for full damages was held not to be a bar to a recovery by the bailor. ${ }^{5}$ It therefore logically followed that the courts should discard such theory of identity of interests of bailor and bailee in determining the question whether the contributory negligence of the bailee should be imputed to the bailor in a suit against a third party for damage to the bailed article. ${ }^{6}$

†LL. B., I927; A.B., I93I, University of Illinois; Assistant Professor of Law at Valparaiso University, Indiana.

${ }^{2}$ Duggins v. Watson, I5 Ark. Ir8 (I854); Welty v. Indianapolis \& V. R. R., I05 Ind. 55, 4 N. E. 4IO (I886) ; Forks Township v. King, 84 Pa. 230 (I876).

a Duggins v. Watson, supra note $\mathrm{I}$.

3 The Beaconsfield, I 58 U. S. 303 , i5 Sup. Ct. 860 (1895).

* Industrial Inv. Co. v. King, I59 Miss. 49I, I32 So. 333 (I93I).

- Peck v. Merchant's T. \& S. Co., 85 Kan. I26, II6 Pac. 365 (Igrr) ; Standard Foundry Co. v. Schloss, 43 Mo. App. 304 (I89I).

${ }^{\circ}$ Wellwood v. King, [I92r] 2 Ir. R. 29o; and cases cited infra note 7. 
Since I900 this question has been raised and decided in twenty-five different jurisdictions. Twenty-one states, the federal courts, and the English Court of Appeal have held that the contributory negligence of the bailee should not be imputed to the bailor in a suit against a third party for damages to the bailed article, unless the relation of master and servant or principal and agent exists between the bailor and bailee. ${ }^{7}$ Two American states have reached a contrary decision. ${ }^{8}$ The basis for the majority view rests entirely upon the theory that contributory negligence should only be imputed to a plaintiff in a suit against a third party, if, under the same relationship, the plaintiff would be liable in a suit by the third party. ${ }^{9}$ This is usually spoken of as the "both way" test. In other words, these cases treat the questions of vicarious liability for negligence and vicarious responsibility for contributory negligence as one and the same. The sole determining factor under this view is the doctrine of respondeat superior.

The contrary result was reached in the case of Langford Motor Co. $v$. McClung Const. Co., ${ }^{10}$ upon the theory that a distinction must be drawn between vicarious responsibility for contributory negligence and vicarious liability for negligence. The court therein conceded that a bailor would not be liable to a third party for the negligence of a bailee; but held that when the bailor sues the third party for injury to the bailed article, the contributory negligence of the bailee will be imputable to such bailor. ${ }^{11}$ It should be noted that such imputed contributory negligence applies only to a suit for injury to the bailed article, and is not equally applicable in a

${ }^{7}$ Sea Ins. Co. v. Vicksburg, S. \& P. Ry., I59 Fed. 676 (C. C. A. 5th, ro08) ; Bradley v. Ashworth, 2II Ala. 395, 100 So. 663 (I924); Featherston v. Jackson, I83 Ark. 373, 36 S. W. (2d) 405 (I93I); Currie v. Consolidated Ry., 8I Conn. 383, 7I Atl. 356 (I908); Tobin v. Syrrit, 32 Del. 274, I22 Atl. 244 (1923); Goldsmith v. Chicago, M. \& St. P. Ry., I76 Ill. App. 336 (I9r3); Lee v. Layton, 167 N. E. 540 (Ind. App. I929) ; Bower v. Union Pac. R. R., I06 Kan. 404, I88 Pac. 420 (I920) ; U-Drive-It-Car Co. v. Texas Pipe Line Co., I4 La. App. 524, I29 So. 565 (1930) ; Robinson v. Warren, I29 Me. 172, 15I Atl. Io (1930); Nash v. Lang, 268 Mass. 407, I67 N. E. 762 (1929) ; Spelman v. Delano, I77 Mo. App. 28, I63 S. W. 300 (Igr4); Lacey v. Great Northern Ry., 70 Mont. 346, 225 Pac. 808 (I924); Cain v. Wickens, $8 \mathrm{r}$ N. H. 99, I22 At1. 800 (I923) ; New York, L. E. \& W. R. R. v. New Jersey Electric Ry., 60 N. J. L. 338, 38 At1. 828 (I897) ; Fischer v. International Ry., rrz Misc. 212, 182 N. Y. Supp. 313 (I920) ; Victor Tea Co. v. Walsh, 38 Ohio App. 516, I76 N. E. 585 (I93I) ; Gibson v. Bessemer \& L. E. R. R., 226 Pa. I98, 75 Atl. I94 (I910) ; Hunt-Berlin Coal Co. v. McDonald Coal Co., I 48 Tenn. 507, 256 S. W. 248 (I923) ; Rutland Buick Co. v. Perry, I58 Atl. 679 (Vt. 1932); Lloyd v. Northern Pac. Ry., I07 Wash. 57, I8I Pac. 29 (I9I9); Calumet Auto Co. v. Diny, I90 Wis. 84, 208 N. W. 927 (1926); Wellwood v. King, supra note 6.

The terms "master and servant" and "principal and agent" have been used synonymously by the courts in the cases under discussion. Possibly the term "master and servant" more nearly describes the situation, for no contractual deals are to be made by an intermediate party for a principal with a third party. For a general discussion of the distinction, see I MECHEM, AGENCY (2d ed. IgI4) \& 36.

${ }^{8}$ Illinois Cent. R. R. v. Sims, 77 Miss. 325,27 So. 527 (1900) ; Langford Motor Co. v. McClung Const. Co., 46 S. W. (2d) 388 (Tex. Civ. App. 1932) ; Munster v. Hexter, 295 S. W. 245 (Tex. Civ. App. I927); Texas \& P. Ry. v. Tankersley, 63 Tex. 57 (I885). at 832 .

${ }^{\circ}$ New York, L. E. \& W. R. R. v. New Jersey Electric Ry., supra note 7 at 347,38 Atl.

${ }_{10}$ Supra note 8.

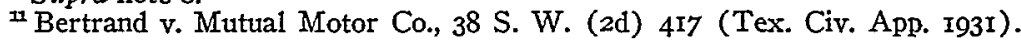


suit by a bailor-passenger for personal injuries. The divergence between these views narrows down to the one question of the legal and social soundness of the "both way" test.

The doctrine of respondeat superior is said to be the sole legal basis for vicarious liability for negligence. Yet this doctrine has been extended to cover so many unorthodox situations ${ }^{12}$ that it becomes necessary to determine what social necessity underlies it. From an examination of its many extensions beyond the orthodox employer and employee relationship, one is led to the conclusion that courts are influenced largely by the desirability of furnishing a financially responsible defendant. In the question of vicarious responsibility for contributory negligence no such necessity exists. This question usually narrows down to the purpose and objective of the doctrine of contributory negligence. Several eminent writers have attempted to find a legal theory as the foundation of this doctrine. They have, however, discarded all the suggested theories and have recognized that the doctrine of contributory negligence is founded upon considerations of public policy, viz., the desire to prevent accidents by inducing each member of the community to conform to the standard of due care imposed by law. ${ }^{13}$ The social objective of vicarious liability for negligence is, therefore, to furnish a remedy, while that of vicarious responsibility for contributory negligence is to prevent future accidents. If this be true, the basis of the majority view in treating the two questions as identical under the "both way" test is unsound and undesirable.

Which view, therefore, the majority or the minority, accomplishes the objective of preventing accidents? It is important to notice that of all the cases prior to I9I9 which established the majority view none were automobile cases, while practically all the cases since that date have been automobile cases. It is a long step from the facts of the first case of the majority view, New York, L. E. \& W. Ry. v. New Jersey Electric Ry., ${ }^{14}$ to those of one of the latest cases, Nash $v$. Lang; $;^{15}$ and yet the court applied the same principle of law without hesitation. In the former case a railroad company was attempting to recover damages from a defendant railroad company for injuries to certain cars while in the possession and use of a bailee railroad company, caused by the concurring negligence of defendant and the bailee. In the latter case a wife was attempting to recover for injury to her automobile from a collision occurring while the automobile was being driven by her husband, a practicing physician, upon a professional call, and caused by the concurring negligence of the defendant and the husband. The husband had purchased the automobile himself, paid for it from his own

${ }^{12}$ Family purpose doctrine as an example, to be discussed infra.

${ }^{13}$ Bohlen, Contributory Negligence, SELECTED EsSAYS ON THE LAW OF TORTS (1924) 469; Schofield, Davies v. Mann: Theory of Contributory Negligence, id. at 543.

it Supra note 7 .

"S Supra note 7 . 
funds, and presented it to his wife as a wedding anniversary present. The wife had had the car registered in her own name and had lent it to her husband for use in making professional calls. After the collision the husband traded in the damaged automobile as part payment of the purchase price of a new one. Upon these facts the court held that the only relationship existing between husband and wife was that of bailee and bailor, and therefore that the husband's contributory negligence could not be imputed to the wife in her suit for property damage to the automobile. ${ }^{16}$

Under this holding it becomes possible for any business man to place the title to the automobile which he uses in his business in his wife's name, ${ }^{17}$ and thereby be assured of the right to recover for damages to the automobile even though he himself be guilty of contributory negligence. In fact, it becomes a question of placing the title of the automobile in the name of the family member who drives the least. ${ }^{18}$ Under such practice, does the majority view tend to prevent accidents, or does it tend to increase accidents by decreasing the opportunity for application of the defense of contributory negligence? The defendant's liability no longer rests upon the question of whether he is merely concurrently or solely negligent, but rests upon the question, in whom is the title of the other automobile vested?

Many automobiles, driven upon the highways by their registered owners, are subject to a conditional sales contract. Under the majority view the conditional seller is merely a bailor. He may disregard his rights against the conditional buyer, and recover from the third party damages to the automobile not in excess of the unpaid purchase price, although such damages were caused by the concurring negligence of the conditional buyer. ${ }^{19}$ It would certainly be enlightening to discover the percentage of

${ }^{16} I d$. at 410,167 N. E. at 763 .

"It might be contended that a court would disregard such a scheme, and hold that the husband was the real owner, even though the automobile was registered in the wife's name. This was not done in the case of Nash v. Lang, supra note 7 . The author has been unable to find a single case, in which the question was the imputation of contributory negligence of the bailee to the bailor, and in which the court disregarded or even suggested that they might disregard the name of the registered owner in determining in whom the title of the automobile was vested. In the case of Cewe v. Schuminski, I82 Minn. I26, 233 N. W. 805 (1930), the court disregarded the name of the registered owner in determining who was the owner of the automobile, but in that case the question was whether a wife could be held liable under the family purpose doctrine for the negligence of her husband. He had purchased the automobile from his own funds and had the title registered in his wife's name although she never drove the automobile. At the time of the collision the husband was returning from a New Year's Eve entertainment at a roadhouse with two other women in his car without the knowledge or consent of his wife. Upon these facts the court held that the wife could not be liable under the family purpose doctrine, as she had nothing to do with the providing and maintaining of this automobile for family use. Such a holding is clearly no intimation that the same court would deny the wife as registered owner the right to sue a third party for damages to the automobile.

${ }_{13}$ Application of the family purpose doctrine will be considered infra.

${ }^{19}$ Lacey v. Great Northern Ry., supra note 7 . The conditional vendor of an automobile sued defendant for destruction of the automobile, caused by the concurring negligence of the conditional vendee and the defendant. The court held that the conditional vendee's contributory negligence could not be imputed to the conditional vendor. However, it was pointed out that the measure of damages is limited to the amount of the purchase price unpaid. 
automobiles driven on our highways at any one time by conditional vendees or by other bailees.

Should this principle of law come to the attention of the general public, and should such knowledge result in a general practice of placing title in the name of the family member who drives the least, it would be a common occurrence to have a collision between two bailees, caused by their concurring negligence; and each bailee would be forced to suffer not the damage to the automobile he was driving but the damage to the other's automobile, recovered in a suit by the other's bailor. ${ }^{20}$ Certainly the result so reached is diametrically opposite to the doctrine of contributory negligence which leaves the losses where they fall. If in the above situation each automobile were covered by liability insurance, covering not only the owner but also any person driving with his consent, the liability insurance would then have become collision insurance, each owner being indemnified for his loss by the other owner's insurance company. One would hesitate to predict the amount of increase necessary in liability insurance premiums in order that the insurance companiese might remain solvent.

Several of the courts have applied this principle to cases where the bailor was present in the automobile as a guest at the time of the collision, holding that presence of the bailor in the automobile as a guest of the bailee will not in itself create a relation of master and servant, so that the bailee's contributory negligence will be imputed to the bailor in a suit by him for injury to his automobile. ${ }^{21}$ Other courts, however, although following the majority rule when the bailor is not present at the time of the collision, hold that if the bailor is an occupant of the car, he has the legal right to control its operation, and therefore a master and servant relationship exists so that the contributory negligence of the driver is imputable to him. ${ }^{22}$ Under the first holding another group of collision cases probably arises where the defense of contributory negligence is unavailable insofar as damage to the

${ }^{\infty}$ Rutland Buick Co. v. Perry, sufra note 7 . This was a suit by the owner of a Buick automobile, driven by a bailee, against defendant, who was driving a $\mathrm{La}$ Salle automobile as bailee. Defendant's bailor had previously recovered a judgment for damage to the La Salle; and the court held that such a judgment would not be a bar to plaintiff's suit to recover damages to the Buick, since the contributory negligence of a bailee is not imputable to the bailor.

7 Rodgers v. Saxton, $305 \mathrm{~Pa}$. 479, I58 Atl. I66 (I93I) ; Virginia Ry. \& Power Co. v. Gorsuch, I20 Va. 655 , gI S. E. 632 (I917) (cases in which the husband was driving and the wife-owner was seated in the front seat).

$\approx$ Martens v. Penton, I5 La. App. 35, I30 So. 354 (I930) (wife driving-husband-owner seated in front seat); Welch v. Louisiana Oil Refining Corp., I7 La. App. roo, I35 So. 6I7 (I93I) (daughter driving - father-owner seated in front seat); Pearson v. Northland Transportation Co., 184 Minn. 560, $239 \mathrm{~N}$. W. 602 (I93I) (son driving-mother-owner riding in auto) ; Gochee v. Wagner, 257 N. Y. 344 , I78 N. E. 553 (I93I) (wife driving-husbandowner seated in rear seat). The New York Court of Appeals stated at 348, 178 N. E. at 554: "When the respondent entered the car, he regained dominion over it and the rule applicable under the statute in the absence of the owner ceased to apply. It was respondent's car, he was present and had the legal right to control its operation, and the negligent conduct of the driver was imputable to him. The mere fact that he chose to sit on the rear seat and refrained from directing its operation did not change his rights or limit his liability." 
automobile is concerned. It is a common occurrence for a wife-owner to ride with her husband-driver as his guest while he is engaged in furthering his own private business.

On the other hand does the minority view, which imputes to the bailor the contributory negligence of the bailee so far as damage to the automobile is concerned, more nearly accomplish the objective of the doctrine of contributory negligence, and more nearly produce social justice? Under this view the defense of contributory negligence rests entirely upon the question of the degree of due care exercised by the parties themselves, and not upon that intangible concept which we speak of as legal title. There is no incentive to the head of a family to place title in another family member in order to circumvent the law. Also, the bailor will exercise more care in determining the competency of the bailee as a driver if he is required to bear the effects of the bailee's contributory negligence. The bailor's sole remedy will be against the bailee; this factor will tend to restrain the lending of automobiles to financially irresponsible drivers. Under this view the doctrine of contributory negligence will be more likely to accomplish its purpose of preventing accidents, since it will be applicable to most collisions caused by concurring negligence of the drivers. ${ }^{23}$

Is there any injustice in holding the bailor responsible for the bailee's contributory negligence? It might be contended that it is legally unsound to hold a bailor responsible for the acts of one over whom he has no control. But has an absentee master any more actual control over the acts of his servant driving the master's automobile? ${ }^{24}$ Yet because the master has the pozver of control, the courts will impute the contributory negligence of the servant to him. In effect, the bailor has the same power of control over the bailee, for he voluntarily creates the bailment and selects the bailee. He may, moreover, limit the scope of the bailment so as to escape responsibility for contributory negligence beyond the scope of the bailment. ${ }^{25}$ Bailors for hire and conditional sellers would not be unduly bur-

${ }^{\infty}$ See infra note 24 .

2s Illinois Cent. R. R. v. Sims, supra note 8. This court, in imputing the contributory negligence of the bailee to the bailor, pointed out the similarity of circumstances between bailor-bailee and master-servant, at 326,27 So. at 527 .

$\approx$ The author was unable to find any case directly on point. Yet it is a well-established principle that the contributory negligence of a servant cannot be imputed to the master, if the servant was acting outside of the scope of his employment at the time. Zutter v. O'Connell, 200 Wis. 598, 229 N. W. 73 (I93I) ; Faust v. Philadelphia \& R. Ry., I9I Pa. 420,43 Ati. 329 ( 1899$)$. It logically follows that if the bailee exceeds the scope of his bailment, the contributory negligence of the bailee would not be imputable to the bailor. In Psota v. Long Island R. R., 246 N. Y. 388 , I59 N. E. I80 (I927), the court recognized the power of a bailor to limit the scope of the bailment to the same extent that a master can limit the scope of employment of a servant. There the plaintiffs were attempting to recover for personal injuries against the owner of an automobile driven by his bailee, under the New York statute rendering the owner liable for the negligence of any person driving his motor vehicle with his consent, express or implied. Plaintiffs were children who had been invited for a ride, contrary to the owner's instructions against inviting strangers to ride in her car. The court upheld the owner's power so to limit the scope of the bailment. 
dened; they would merely be forced to treat this as an additional business risk to be covered by collision insurance.

\section{Under Legislation}

The legislatures of several states have felt the social necessity of establishing vicarious liability of the bailor for the negligence of the bailee, and have enacted statutes which in substance render the owner of a motor vehicle liable for the negligence of any person driving such motor vehicle with his consent, express or implied. These statutes were enacted for the purpose of creating liability on the part of the bailor toward third parties injured by the bailee's negligence, and it is very likely that at the time of their enactment no consideration was given to the question of the bailor's vicarious responsibility for contributory negligence of the bailee in the bailor's suit against the third party. For the purpose of determining their applicability to this situation, these statutes may be divided into three classes as follows:

(I) Those which expressly create the relationship of master and servant or principal and agent between the bailor and bailee. ${ }^{26}$

(2) Those which create a lien against the automobile for the benefit of the third party. ${ }^{27}$

(3) Those which create liability on the part of the bailor without describing the relationship existing thereunder between such bailor and his bailee. ${ }^{28}$

As to the first type of statute, Rhode Island is the only state which has attempted to describe the basis of liability in the statute itself. ${ }^{29}$ This statute expressly creates the relationship of principal and agent between the owner and operator. Its effect, therefore, is merely to apply the doctrine of respondeat superior. This being true, the owner of the automobile who lends it with his consent, express or implied, is no longer a mere bailor, but becomes a master or principal and the driver his servant or agent. Then

Under such a rule the result reached in Wellwood v. King, supra note 6, would be the same under the minority view as under the majority view. In that case the owner left his automobile at a garage for repairs with no authorization to drive it. The act of the garage employee in driving the automobile at the time of the collision would be outside the scope of the bailment.

${ }^{\circledR}$ R. I. Public Laws 1927, c. I040, §3.

$\pi$ S. C. CODE OF LAWS (1932) \$8785; TENN. CODE (I932) \$2700.

${ }^{2}$ CaI. CIV. Cone (Deering, I93I) \& I7I4I/4; ConN. GEN. STAT. (1930) § I627; Iowa Code (I93I) § 5026; ME. Rev. Stat. (I930) c. 29, \$ 99; MiCh. Comp. LAws (I929) \$ 4648; N. Y. Cons. Laws (Cahill, I930) c. 64-2, \$59.

${ }^{9} \mathrm{R}$. I. Public Laws 1927, c. 1040, \&3: "Whenever any motor vehicle shall be used or operated upon any public highway of this state with the consent of the owner or lessee or bailee thereof, express or implied, or under any agreement with such owner or lessee or bailee, express or implied, the operator thereof, if other than such owner, shall in case of accident, be deemed to be the agent of the owner of such motor vehicle, and the agent of such lessee and of such bailee." 
the common law rule that imputes to a master or principal the contributory negligence of the servant or agent becomes applicable. Thus in Rhode Island the minority view is in effect by virtue of this statute.

A I929 amendment, however, provides that the statute shall not be applicable if the operator furnishes evidence of financial responsibility prior to such accident. ${ }^{30}$ Does this amendment have the effect of denying the application of the statute to the question of imputed contributory negligence? The statute, with the amendment added, seems to show on its face that the legislature did not intend it to cover the question of imputed contributory negligence; for why should the question of the owner's responsibility for the driver's contributory negligence in a suit against a third party depend upon whether the driver had furnished evidence of financial responsibility? Of course, if the driver is financially responsible, there is no necessity for making the owner liable; but should the fact that the driver was financially responsible prevent the third party setting up the defense of contributory negligence, when the owner attempts to recover for damage to the automobile? Apparently the amendment shows a legislative intent that the agency, created between owner and driver, should apply only when a third party sues, and not when the owner sues the third party.

As to the second type of statute, Tennessee and South Carolina have enacted statutes which in substance provide for a lien on any motor vehicle for damages caused by its operation while being operated by owner, servant, or bailee. ${ }^{31}$ Both statutes have been construed as creating an additional remedy, in rem against the automobile, but as in no way affecting the common law rule of respondeat superior with reference to the owner's personal liability. ${ }^{32}$ Therefore, if the statutes in no way affect the common law rule of vicarious liability for negligence, then clearly they can have no application to the question of vicarious responsibility for contributory negligence. ${ }^{33}$

${ }^{30}$ R. I. Public Laws I 29 , c. I429, § 10: “. . . unless such operator shall have furnished evidence of financial responsibility in the amounts set forth in Section 7 hereof, prior to such accident."

${ }^{31}$ TENN. CODE (1932) §2700: "Whenever any suit for damages is brought for injuries to person or property sustained while any motor vehicle was run in excess of twenty miles per hour, there shall be a lien on such motor vehicle in event of, and for the satisfaction of such recovery, as the court may award, whether, at the time of injury, such motor vehicle was driven by the owner thereof, or by his chauffeur, agent, employee, servant or any other person using same by loan or hire."

S. C. CoDE of LAws (1932) $\$ 8785$ : "When a motor vehicle is operated in violation of the provisions of law, or negligently and carelessly, and when any person receives personal injury thereby, or when a buggy or wagon or other property is damaged thereby, the damages done to such person or property shall be and constitute a lien next in priority to the lien for State and county taxes upon such motor vehicle, recoverable in any court of competent jurisdiction, and the person sustaining such damages shall have a right to attach said motor vehicle in the manner provided by law for attachments in this State: Provided, That this section shall not be effective in case the motor vehicle shall have been stolen by the breaking of a building under a secure lock, or when the vehicle is securely locked."

${ }^{32}$ Hall v. Locke, II8 S. C. 267 , IIo S. E. 385 (I92I) ; Core v. Resha, I40 Tenn. 408, 204 S. W. II49 (I9I8).

${ }^{33}$ Apparently that is the conclusion reached in Tennessee; for the court in the case of Hunt-Berlin Coal Co. v. McDonald Coal Co., supra note 7, failed even to mention this statute in adopting the common law rule followed by the majority of the states. 
However, a liberal-minded court might interpret the statute as an attempt to identify the negligence of the driver with the automobile, and thereby reach the conclusion that the contributory negligence of the driver was so identified with the object causing the damage, the automobile, as to preclude the owner from recovering for any damage to it. Such an interpretation would certainly be a novel proposition of law. ${ }^{34}$

As to the third type of statute, New York, Michigann, Iowa, and California have enacted statutes which in substance provide that the owner of a motor vehicle shall be liable for injuries to person and property resulting from the negligence of the driver, operating such motor vehicle with the owner's consent, express or implied. ${ }^{35}$ In these statutes the legislatures have made no attempt to describe the basis of such liability. However, the courts have been uniform in holding that the legislatures intended to create a relationship of master and servant or principal and agent between the owner and driver. ${ }^{36}$ This is in effect a statutory extension of the doctrine of respondeat superior. ${ }^{37}$ If these statutes do create the relationship of master and servant or principal and agent between the owner of a motor vehicle and any person driving with his consent, then such relationship

${ }^{3}$ Such an interpretation would probably never be reached under our strict rules of interpretation of statutes changing the substantive law. Yet the statute clearly shows a legislative intention to deprive the owner of the value of his automobile, if it causes damage through negligence of the driver, without any consideration of the question of respondeat superior. If the doctrine of respondeat superior is abrogated when a third party sues so far as the value of the automobile is concerned, does that not show a legislative intent to also abrogate the doctrine when the owner sues for the value of the automobile?

${ }^{3} N$. Y. CoNs. LAws (Cahill, I930) c. 64-a, $\$ 59$ : "Every owner of a motor vehicle or motor cycle operated upon a public highway shall be liable and responsible for death or injuries to person or property resulting from negligence in the operation of such motor vehicle or motor cycle, in the business of such owner or otherwise, by any person legally using or operating the same with the permission, express or implied, of such owner."

MICH. Comp. LAws (1929) $\$ 4648$ : "The owner of a motor vehicle shall be liable for any injury occasioned by the negligent operation of such motor vehicle whether such negligence consists of a violation of the provision of the statutes of the state or in the failure to observe such ordinary care in such operation as the rules of the common law require. The owner shall not be liable, however, unless said motor vehicle is being driven with his or her express or implied consent or knowledge."

Iowa CODE (I93I) $\$ 5026$ : "In all cases where damage is done by any car driven by any person under fifteen years of age and in all cases where damage is done by the car, driven by consent of the owner, by reason of negligence of the driver, the owner of the car shall be liable for such damage."

CAL. Crv. CoDE (Deering, 1931) § I714\%/4: "Every owner of a motor vehicle shall be liable and responsible for the death of or injury to person or property resulting from negligence in the operation of such motor vehicle, in the business of such owner or otherwise, by any person, using or operating the same with the permission, express or implied, of such owner ..."

${ }^{*}$ Maine v. James Maine \& Sons Co., 198 Iowa 1278,201 N. W. 20 (I924). In Psota v. Long Island R. R., supra note 25 , at 393 , I59 N. E. at I8I, the court stated: "Prior to the enactment of this section, the law was that an owner was not liable for the negligence of a person to whom he had loaned his car, whether that person was a member of his family, a servant on a personal errand, or a stranger. ... The Legislature determined to change this law and did change it by this section of the Highway Law so as to make the owner liable for the negligence of a person to whom he loaned the car in connection with its operation upon the highway. Such person was no longer a stranger to the owner, but became to this extent the owner's agent. The owner assumed this liability under the law and took this risk in loaning his car."

${ }^{\Im 7}$ Maine v. James Maine \& Sons Co., supra note 36. 
exists not only when the third party is suing the owner, but also when the owner is suing the third party. It logically follows, therefore, that the contributory negligence of any person driving the motor vehicle with the owner's consent, express or implied, would be imputed to the owner in his suit against the third party for damage to the motor vehicle.

This was the result unanimously reached by the court in the case of Secured Finance Co. v. Chicago, R. I. \& P. Ry. ${ }^{3 s}$ In that case the plaintiff had gratuitously lent his automobile to a friend for the latter's personal use. As a result of the concurring negligence of the defendant and the friend, the automobile was damaged. The Supreme Court of Iowa denied the plaintiff the right to recover for damage to the automobile as against the defendant, upon the theory that under the Iowa statute the contributory negligence of the friend was imputable to the plaintiff. The court argued that since the basis of the majority rule at common law, which refused to impute to the bailor the bailee's contributory negligence, was based upon the principle that since the bailor was not liable for the bailee's negligence he could not be responsible for the bailee's contributory negligence. ${ }^{39}$ It therefore follows that under this statute the bailor, being liable for the bailee's negligence, ${ }^{40}$ also becomes responsible for the bailee's contributory negligence. This is merely the application of the "both way" test to the same situation as under the majority view at common law.

In New York this view was followed in the case of Swarthout $v$. Van Auken ${ }^{41}$ and in the case of Shuler $v$. Whitmore. ${ }^{42}$ However, in the case of Gochee v. Wagner, ${ }^{43}$ the Appellate Division of the New York Supreme Court reached a contrary result. The decision, which was by a divided court, ${ }^{44}$ was reached upon the theory that the statute was remedial solely for the benefit of the third party, and should therefore be limited to the situation where the third party sues the owner. Certainly if the statute was enacted for the benefit of the third party, it would be most beneficial if the third party was also able to set up the defense of contributory negligence against the owner. The dissenting opinion points out that the Court of Appeals of New York has already in the case of Psota. v. Long Island $R . R .^{45}$ held that the statute creates the relation of master and servant or principal and agent between the owner and the driver, and consistently carried it through to its logical conclusion in that case. It is also pointed out

${ }^{38} 207$ Iowa 1105,224 N. W. 88 (1929).

${ }^{50}$ The "both way" test.

${ }^{10}$ See Secured Finance Co. v. Chicago, R. I. \& P. Ry., supra note 38, at II06, 1107, 224 N. W. at 88,89 .

132 Misc. 89, 228 N. Y. Supp. 671 (1928), aff'd on other grounds, 235 N. Y. Supp. 732 ( 1929 ).

I38 Misc. 8I4, 246 N. Y. Supp. 528 (1930), aff'd 25I N. Y. Supp. 886 (I93I).

(3)e 232 App. Div. 40r, 403, 250 N. Y. Supp. 102, 105 (I93I).

"Three to two decision.

«s Supra note 36 . 
that, under the decision of the majority of the judges, if a collision occurs between two bailees through their concurring negligence, each owner will be able to recover from the other owner the amount of damage to his own automobile. ${ }^{46}$ Thus, if there is a collision between a Ford and a Rolls-Royce as a result of concurring negligence, both being driven by bailees, the Ford owner will be forced to pay for the damage to the Rolls-Royce and the RollsRoyce owner for the damage to the Ford-certainly a remarkable legal result. The decision of the Appellate Division was reversed by the Court of Appeals, ${ }^{47}$ without discussion of the applicability of the statute, upon the grounds that the presence of the bailor in the automobile at the time of the collision created a master and servant relationship. ${ }^{48}$ Thus the question of the bailor's vicarious responsibility for contributory negligence of the bailee under this statute remains an open question in New York.

The New York statute, however, contains a provision exempting from its application any person engaged in the business of renting or leasing motor vehicles who carries public liability insurance. ${ }^{49}$ This exemption is similar to that already discussed in the Rhode Island statute, and raises the same question whether the exemption does not indicate a legislative intent to deny the application of the statute to the question of imputed contributory negligence; for why should the responsibility of the bailor for hire for the contributory negligence of the driver depend upon whether such bailor carries public liability insurance? Of course, if the bailor carries public liability insurance covering the driver, there is no necessity for making the owner liable in a suit by the third party; but should the fact that such public liability insurance is carried prevent the third party setting up the defense of contributory negligence, when the owner attempts to recover for damages to the automobile?

Connecticut and Maine also have statutes of the third type, but by their terms they are limited to bailments for hire. ${ }^{50}$ The Connecticut statute has been construed as being contractual in its nature, and therefore a part of every contract of bailment for hire entered into within the state. Under this interpretation the rights of the injured third party rest upon the theory of third party beneficiary and not upon the doctrine of respondeat

${ }^{20}$ Supra note 43 , at $406,250 \mathrm{~N}$. Y. Supp. at I07.

$" 257$ N. Y. 344, I78 N. E. 553 (193I).

supra note 22.

$\omega$ N. Y. Cons. Laws (Cahill, 1930) c. 64-a, §59: “. . . provided, however, that any person, firm, association or corporation engaged in the business of renting or leasing motor vehicles to be operated on the public highway, who carries or causes to be carried public liability insurance in an insurance company or companies approved by the insurance commissioner insuring the renter against liability arising out of his negligence in the operation of such motor vehicle, in limits of not less than five thousand dollars for any one person injured or killed and ten thousand dollars for any number more than one injured or killed in any one accident, and against liability of the renter for property damage in the limit of not less than one thousand dollars for one accident, shall not be subject to the provisions of this section."

${ }^{5}$ Supra note 28 . 
superior, and such statute is thereby given extra-territorial effect. ${ }^{51}$ Under such a construction the statute can have no application to the question of imputed contributory negligence.

Having held that an automobile in operation is a dangerous instrumentality, ${ }^{52}$ the Florida Supreme Court reached the conclustion that the statutes, providing for the licensing and registration of all automobiles operated upon the public highways under the names of the owners, ${ }^{53}$ must be construed as rendering the owner of an automobile liable for the negligence of any person driving such automobile with the owner's consent. ${ }^{54}$ This conclusion was reached upon the basis that a license for operation of any automobile is nontransferable by the owner, and therefore that any person operating a licensed automobile with consent of the owner is an agent of such owner..$^{55}$ If the driver is an agent of the licensed owner so as to render the owner liable for his negligence in a suit by a third party, then such driver is also an agent for the licensed owner when the latter is suing the third party for damage to the automobile, and any contributory negligence of the driver will be imputed to the owner in such suit. Thus in Florida, by a liberal construction of the registration and licensing statutes, the court has reached the same result as has been reached in Iowa, New York, Michigan, and California by express statutory provisions.

The enactment of compulsory automobile liability insurance laws raises the questions of their effect upon vicarious liability for negligence and vicarious responsibility for contributory negligence. A Massachusetts statute provides, as a condition to registration and licensing of an automobile, that the owner must furnish a liability bond or a liability insurance policy, either of which must cover liability from operation of such automobile by the owner or any person operating such automobile with the owner's consent, express or implied.56 The effect of such statute is to assure the collection of a judgment by an injured third party against a financially irresponsible bailee. However, does the statute in any way render the bailor personally liable for negligence of the bailee? This statute has been construed as in no way affecting the common law rules of vicarious liability for negligence, and therefore as no extension of the doctrine of respondeat superior to the relationship of bailor and bailee. ${ }^{57}$ Clearly if the statute does

* Levy v. Daniels' Renting Co., I08 Conn. 333, I43 Atl. I63 (1928). The accident occurred in Massachusetts while the contract of bailment was entered into in Connecticut. Suit was brought in Connecticut and the court held the statute applicable.

${ }^{5}$ Southern Cotton Oil Co. v. Anderson, 80 Fla. 44I, 86 So. 629 (I920).

${ }^{5}$ FLA. COMr. LAwS (I927) § I 280 et seq.

* Herr v. Butler, ror Fla. II25, I32 So. 8I5 (I93I); Engleman v. Traeger, 102 Fla. 756, I36 So. 527 (I93I). In Williams v. Younghusband, 57 F. (2d) I39 (C. C. A. 5th, I932), the Circuit Court of Appeals refused to follow the Florida Supreme Court decisions.

${ }^{5}$ See Engelman v. Traeger, silpra note 54 , at $759,764,136$ So. at 529,531 .

co Mass. Gen. Laws (1932) c. 90, $\$ 34 \mathrm{~A}-J$.

${ }^{57}$ McNeil v. Powers, 266 Mass. 446 , I65 N. E. 385 (r929). Defendant's automobile was being operated by his brother with his consent at the time of the collision. Plaintiff con- 
not affect the common law rules of vicarious liability for negligence, it canent affect the common law rules of vicarious responsibility for contributory negligence. ${ }^{58}$

In New Jersey a very unusual situation is presented by a statute requiring compulsory liability insurance of all persons engaged in the business of renting and leasing motor vehicles without a driver. The statute provides that the policy or policies of insurance must insure "such motor vehicle owner against loss from liability imposed by law upon such motor vehicle owner for damages-occurring by reason of the negligent maintenance, use or operation of such motor vehicle upon the public highways of this State." :9 But, at common law, there is no "liability imposed by law" upon the bailor for hire for the negligence of the bailee. Nor is there any such liability imposed by any statute in New Jersey. Therefore, if the statute is strictly construed, the insurance required is valueless, and the statute is rendered nugatory. However, a New York court construed this statute as creating a statutory liability upon the part of a bailor for hire for negligence of the bailee. The basis for this decision was that the statute showed a legislative intent to protect the public by providing a financially responsible defendant. ${ }^{60}$ If this construction is sound, then this statute may be classified as belonging to the third type; and it raises the same question whether it creates a relationship of master and servant or principal and agent between bailor for hire and bailee, so that the latter's contributory negligence might be imputed to the former in a suit for damage to the automobile.

\section{Under the Family Purpose Doctrine}

The increased use of the automobile as an instrument of pleasure for the benefit of the family, coupled with the practice of permitting minor members of the family to drive the family automobile for their own pleasure, has raised the problem of furnishing a financially responsible defendant in cases of injury or damage to third persons. A considerable number of states, but less than half, have solved this problem by the adoption of

tended that under the compulsory automobile insurance law the defendant was absolutely liable without proof of agency. The court in discussing the statute stated: "The meaning of these words is that the bond required to be given is a security for judgments rendered not only against the obligor of the bond, but also against the person responsible for the operation of the car with the express or implied consent of the owner. That was an important extension of protection previously afforded to those injured by automobiles upon public ways. It did not, however, go so far as to make the owner of the motor vehicle responsible for the negligence of one not his servant or agent although operating his motor vehicle with his knowledge and consent."

${ }^{\varpi}$ In Nash v. Lang, supra note 7 , the court failed even to consider this statute in adopting the majority view at common law.

${ }^{z}$ N. J. Comp. Stat. (Supp. I930) p. I052.

${ }^{\infty}$ Grimshaw v. Gnudi, I36 Misc. 443, 240 N. Y. Supp. Ig9 (I930). Defendant was engaged in the business of leasing automobile for hire without a driver in New Jersey. Plaintiff was injured in New Jersey by the negligent driving of a lessee of defendant. 
what is known as the family purpose doctrine. ${ }^{61}$ Under this doctrine the owner of an automobile which he supplies to his family for their pleasure is held liable for the negligence of any member of the family driving such automobile for his own pleasure with the consent, express or implied, of such owner. ${ }^{62}$ The basis for this liability is said to be a relationship of master and servant or principal and agent existing between the owner of the family automobile and the member of his family driving it. The owner, by placing his automobile at the disposal of his family, makes the pleasure of his family or any member thereof, driving the machine with his consent, his "affair and business" within the scope of the doctrine of respondeat superior. ${ }^{63}$

The adoption of this doctrine has resulted solely from the social necessity of creating vicarious liability for negligence in this situation. However, since the basis of this doctrine is the application of the principle of respondeat superior, is not the doctrine equally applicable to create vicarious responsibility for contributory negligence? If the owner of the family automobile is liable for the negligence of a member of his family, driving with his consent, express or implied, in a suit by a third party under the rule of respondeat superior, then such owner is clearly responsible for the contributory negligence of such member of his family in a suit against the third party for damage to the family automobile. ${ }^{64}$

Apparently the adoption of this doctrine will prevent the practice of avoiding the defense of contributory negligence by placing title to the family automobile in the member of the family who drives the least, as previously suggested. But the question then arises as to what situations within the family this doctrine will apply. First it must be kept in mind that the family purpose doctrine is applicable only where the driver is a member of the owner's family. Therefore the majority rule, denying the imputation of contributory negligence of the bailee to the bailor, applies where the driver is outside the family circle, and no agency in fact can be shown.

${ }^{61}$ See Lattin, Vicarious Liability and the Family Autonobile (1928) 26 MrCH. L. REv. 846 , for a review of the authorities supporting and denying this doctrine.

${ }^{2} I d$. at 86I: "In order to bind the family owner, five requisites are necessary:

"(I) A general or special property interest by the family owner in the automobile.

"(2) The car must be furnished or kept for family use.

"(3) There must be a family relationship between the driver and the owner-he must be, at the time of the accident, a 'member of the owner's family'.

"(4) Permissive use by the member driving.

"(5) Accident by member while using it on one of the permissive uses for which the car was bought."

${ }^{6} I d$. at 848 .

at Prendergast v. Allen, 44 R. I. 379, II7 At1. 539 (I922) ; Pearson v. Northland Transportation Co., supra note 22 . In both cases, however, the owner, who was suing for personal injuries and damage to the family automobile, was present in the machine at the time of the accident. In the first case the decision could have been reached upon the theory of a joint enterprise; but in the second case the driver of the family automobile was clearly upon his own business, with the owner present in the car merely as a guest. 
In most of the cases which have established this doctrine the owner was the father and the driver was a minor son or daughter. But in all cases where the question has been raised, the courts have held the doctrine equally applicable where the owner was the husband and the driver was his wife. $^{05}$ In many of the cases the courts in stating the doctrine have used the terms "paterfamilias" or "head of the family" when referring to the owner of the family car. As a result, the question is raised whether the family purpose doctrine must be limited to cases where the owner of the automobile is the head of the family, or whether it includes also cases where the owner is a member of the family not its head, such as a son, daughter, or wife.

Where a wife, while living with her husband, owns an automobile as her separate property and furnishes it for use of the family for its pleasure, the family purpose doctrine has been held applicable so as to render her liable for the negligence of a minor child driving such automobile for its own pleasure with her consent. ${ }^{66}$ A wife has an equal interest with her husband in the welfare and pleasure of the minor children and she as well as her husband can make the pleasure of the minor children her "affair and business", so as to create a relationship of master and servant or principal and agent between herself and the minor children when using her automobile with her consent for their own pleasure. However, where a husband is driving his wife's automobile upon his own pleasure or business, an entirely different question arises. Does a wife have sufficient interest in her husband's personal pleasure or business, so that the furnishing of an automobile for his use will make his personal pleasure or business her "affair and business"? In Kennedy v. Wolf ${ }^{67}$ the Court of Appeals of Kentucky held that the family purpose doctrine was inapplicable to the use by a husband for his own business or pleasure of his wife's automobile, because the husband was himself the head of the family and not the wife. In those cases where the wife has been held liable for the husband's negligence in driving her car, the facts have established either an agency in fact or a joint enterprise. ${ }^{68}$ If the application of the family purpose doctrine must be so limited, then the opportunity for a husband to escape the defense of con-

$\approx$ Hutchins v. Haffiner, 63 Colo. 365, I67 Pac. 966 (I917) ; Tarleton-Gaspard v. Malochee, I6 Ia. App. 527, I33 So. 409 (I93I) ; Plasch v. Fass, I44 Minn. 44, I74 N. W. 438 (IgI9); Gross v. Williams, Ig6 N. C. 213 , I45 S. E. I69 (rg28); Ulman v. Lindeman, 44 N. D. 36, I76 N. W. 25 (I9I9); Smith v. Jamison, 89 Pa. Super. 99 (I926) ; Cohen v. Hill, 286 S. W. 661 (Tex. Civ. App. I926).

${ }^{c}$ Guignon v. Campbell, 80 Wash. 543, I4I Pac. I03I (I914); Steele v. Age's Adm'x $233 \mathrm{Ky} .7 \mathrm{I} 4,26 \mathrm{~S}$. W. (2d) 563 (I930). In both cases the wife was living with her husband at the time of the accident.

or $221 \mathrm{Ky}$. III, II3, $298 \mathrm{~S}$. W. I88, I89 (I927). Kentucky had previously adopted the family purpose doctrine to its fullest extent. Stowe v. Morris, I47 Ky. 386, I44 S. W. 52 (I9I2).

${ }^{6}$ In Venghis v. Nathanson, xor N. J. L. I10, 127 Atl. I75 (1925), the husband was driving to the home of his parents to get his wife at her express direction. In Prendergast $\mathrm{v}$. Allen, supra note 64 , the wife was present in the automobile with her husband driving, while returning from a day's outing at a lake. 
tributory negligence to the extent of damage to the automobile, while using such automobile in his business or pleasure, by placing title in his wife's name, still exists; and the adoption of this doctrine has failed to remedy the situation existing in the case of Nash v. Lang. ${ }^{69}$

A similar problem arises when a son or daughter furnishes an automobile for use of his or her parents. Certainly, if the son or daughter is an adult maintaining his or her own household, and the parents are living therein as members of the family, the family purpose doctrine is applicable. ${ }^{70}$ But where the son or daughter is living with his or her parents, not as head of a family, but as a member of their family, an entirely different question arises. $^{71}$ Does such a son or daughter have a sufficient interest in the pleasure of the parents so that the mere furnishing of a family automobile will make their pleasure his or her "affair and business"? By analogy to the situation where the wife is owner and the husband is driving on his personal business, it would appear that the family purpose doctrine is inapplicable; and therefore that the contributory negligence of the parent-driver would not be imputed to the son-owner or daughter-owner in a suit for damage to the automobile.

A further limitation upon the application of the family purpose doctrine has been recognized. The member of the owner's family driving the automobile at the time of the accident must have had general authority to drive such machine for his own pleasure. Special permission to use the automobile for that particular occasion, without proof of general authority to drive, either express or implied, will create merely a bailment relationship. ${ }^{72}$ Thus, a considerable group of cases, in which a father maintains a family automobile but permits his children to drive it only by special permission, falls outside the scope of the family purpose doctrine; and the father is permitted to recover damages to his automobile free from the defense of contributory negligence of the driver.

This problem of vicarious responsibility for contributory negligence in automobile bailments has always been approached and considered as a corollary to the problem of vicarious liability for negligence. The courts which have refused to adopt and follow the family purpose doctrine have felt

${ }^{\infty}$ Supra note 7.

${ }^{70}$ In Crouse v. Lubin, $260 \mathrm{~Pa}$. 329, ro3 Atl. 725 (I918), the court applied the family purpose doctrine to a wife-owner for negligence of her mother. The wife-owner was living with her husband at their own home, and her mother lived there as a member of their family. In Turner v. Gackle, I68 Minn. 5I4, 209 N. W. 626 (I926), the court applied the family purpose doctrine to a son-owner for negligence of his father. The facts given in the opinion are meager, but it can be gathered that the son was an adult in business with his father, and the father was a member of the son's family.

7 The author was unable to find any case deciding this question. Its existence was recognized in Morken v. St. Pierre, 147 Minn. 106, 179 N. W. 681 (1920), but not decided. The owner of the automobile was a son living with his parents. The automobile was being driven by a brother under the control of his mother at the time of the accident.

т2 O'Keefe v. Fitzgerald, I06 Conn. 294, I37 Atl. 858 (1927); Maher v. Fahy, I1z Conn. 76, I5I At1. 318 (1930). 
that it creates liability upon a mere bailment relationship. There may be social reasons why the courts should not by judicial legislation create vicarious liability upon the part of a bailor for negligence of his bailee. Yet these social reasons do not have the same force and effect upon the problem of vicarious responsibility for contributory negligence of the bailee. It is therefore necessary for the courts to divorce these two problems from each other. If this is done, it will be possible to approach the latter problem from the viewpoint of its social needs. The minority rule, which imputes to the bailor the contributory negligence of the bailee so far as the damage to the bailed article is concerned, more nearly meets the requirements of society since the advent of the automobile. One eminent judge, in speaking of the problem of development of the common law to meet social needs, stated: "Finally, when social needs demand one settlement rather than another, there are times when we must bend symmetry, ignore history and sacrifice custom in pursuit of other and larger ends." 73

${ }^{73}$ Cardozo, The Nature of the Judicial Process (Ig2I) 65. 